\title{
FACTORS CAUSING THE TRANSFER OF FOREST FUNCTION TO CORN FARMING LAND IN DOMPU REGENCY
}

\author{
Mita Parasti ${ }^{1}$, M.Firdaus ${ }^{2}$, Ahmad Maulana Mallivera ${ }^{3}$, Aulia Putri ${ }^{4}$ Diah Rahmawati $^{5}$ \\ 1,2,3,4,5 Universitas Muhammadiyah Mataram \\ JL.KH.Ahmad Dahlan no. 1 Pagesangan \\ Email corresponding: mita.parasti@gmail.com
}

\begin{tabular}{|c|c|c|}
\hline Submitted: & Accepted: & Published: \\
$16-07-2021$ & $08-08-2021$ & $30-09-2021$ \\
\hline
\end{tabular}

\begin{abstract}
Nature is a component that plays an important role in human life. This big role cannot be separated from the provision of ecosystem services to fulfill needs in order to support life. These ecosystem services will not run properly if there is environmental damage. This environmental damage begins with the conversion of forest functions into corn agricultural land, humans only think about how to fulfill their desires without thinking about the impact it will have on nature and other humans. The purpose of this research is to find out the impact of land conversion which will change the function of the forest which should be the heart of earth's life into a corn farming field which will only benefit the parties concerned. Methods of collecting data using the interview method, direct observation of the field by looking at the existing conditions directly in the field. The results of this research show that there is a change in the function of forest land into corn agricultural land and changes the function of the area. Factors causing the conversion of forest functions are displacement, land use, economy and weak legislation.
\end{abstract}

Key words : Environment, forest conversion, agriculture

\section{INTRODUCTION}

Forests located within the territory of the Unitary State of the Republic of Indonesia (NKRI) is a natural wealth controlled by the state. This is affirmed by the Law of the Republic of Indonesia number 41 of 1999 concerning forestry in article 4 concerning forest tenure. Where as an economic buffer (Maha \&Masbar, 2018). Forests are the heart of the earth that maintains the stability of life in them. The forest has given everything to the indigenous peoples who live around the forest. They obtained foodstuffs, medicines, ritual tire clothing and so on (Devrayno, 2015). Forests are dominated by a variety of trees and biological resources that provide life for living things. These biological resources must be preserved to meet future needs. The forest has performed its function but as a social being that is selfless is to maintain and not damage the function of the forest by performing the transfer of forest functions. Land transfer is a change of function of part or all of the land area from its original function (as planned) to another function that becomes a negative impact (problem) on the environment and the potential of the land itself (Kusumaningtyas \&Chofyan, 2013).
Dompu regency is a hot climate so it is suitable for agricultural land, especially corn, as a result of land function transfer. The transfer of forest functions is rampant in Indonesia, one of which is in Dompu Regency. The transfer of forest functions into agricultural land for corn and other types of agriculture, it can be driven by several factors including, the amount of demand for agricultural commodities, following the desire not the need so as not to pay attention to the impact that will arise as a result of the transfer of land functions that change the function of land that should be the heart of the earth into corn fields that only benefit some parties. In fulfilling the needs of his life, human activities to nature always cause damage to the environment itself (Zairin, 2016). Land transfer can also be interpreted as a change for other uses due to factors that broadly include the need to meet the needs of a growing population and the increasing demands for a better quality of life (Kapantow et al., 2015).

Changes from forests to maize farms will lead to changes in vegetation structure and composition of growing species, as well as layers of soil surface, this condition can have an impact on the loss of biodiversity native habitat above ground level mainly due to the influence of compaction and decrease in 
macro pores due to tree felling and management carried out in Dompu Regency. The decrease in soil aggregate stability is related to the decrease in soil organic matter content, plant rooting activity and soil microorganisms. The decrease of the three soil aggregate binding agents in addition to causing soil aggregates are relatively easily broken so that it becomes an aggregate or smaller particles also cause the formation of crusts at the surface of the soil (soil crusting) that has solid and hard properties when dry. Fine aggregates or particles ofparticles will be carried by water flow into the soil causing clogging of soil pores (Tolaka et al., 2013)

Clearing forests into agricultural areas can occur soil damage at the beginning with a decrease in soil aggregate stability due to rainwater blows and surface runoff strength in addition to causing soil aggregates relatively easily broken so that it becomes an aggregate or smaller particles, also causing the formation of crusts on the ground surface that are dense and hard when dry. Fine aggregates or particles will be carried by water flow into the soil causing clogging of soil pores. When it rains, the crust that forms at the surface of the soil also causes blockage of soil pores. Due to this process of soil pore blockage, soil porosity, soil pore distribution and soil's ability to drain water decrease and surface runoff will increase. Erosion in the accelerated will occur, so it will eliminate large amounts of top soil, organic matter and nutrients. Changes in these conditions will lead to degradation, decreased water catchment function, increased erosion, surface runoff, landslides, decreased land area and will cause flooding in the Dompu District. One of the impacts of land conversion that is often in the spotlight of the wider community is the disruption of food security, problems that arise permanently or will still be felt in the long term even though land convection is no longer the case (Irawan, 2005). To prevent uncontrollable land transfer, policy taking must have adequate data and information related to factors that affect farmers to transfer land functions. Therefore, in this paper, the results of identification about what factors encourage farmers to transfer land functions. Case study in Dompu Regency. Therefore, based on the background, it is necessary to conduct a study on the impact of the transfer of forest land function into corn farmland.

\section{METHODS}

\section{Research Approaches and Stages}

This study uses qualitative descriptive research. The result of this study is a factor that affects the transfer of forest function to corn farming land in Dompu Regency.

Data Collection Methods

The data in this study was collected through field observation and secondary data. For secondary data taken from dompu data as the location of land function transfer. Primary observation or field observation by looking directly at existing conditions in the field related to the condition of the transfer of forest functions to agricultural land. This method of supporting data collection uses interviews to the government (PUPR office), community leaders (village heads) and the local community of Dompu Regency.

Stages of Research

The stages in this study are described in the following graph.

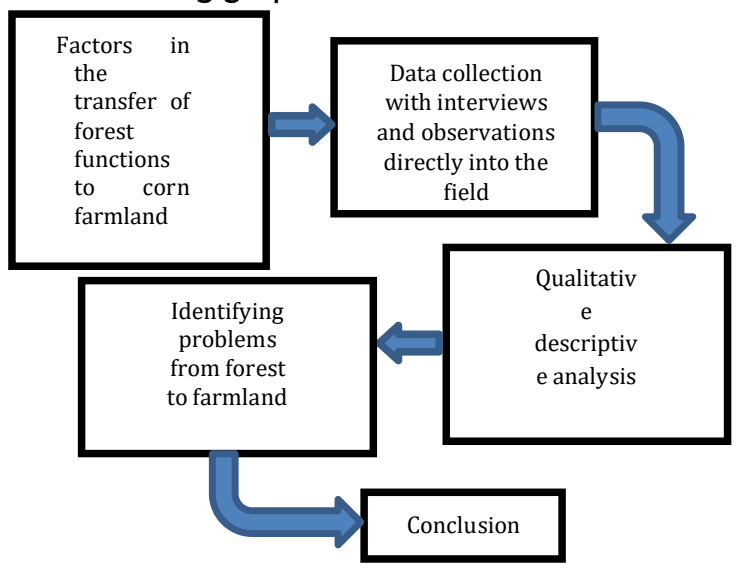

Figure 1. Stages of Research

\section{RESULTS AND DISCUSSION}

\section{Overview}

Dompu Regency is one of the 9 (nine) regencies/cities located in the province of West Nusa Tenggara, located on sumbawa island, with an area of 2,324.55 Km2. Geographical location of Dompu Regency is located between $117042^{\prime}$ - 1180 30' East Longitude and 80 06' - 90 05' South Latitude with the following boundaries: North: Flores Sea and Bima Regency, South Side: Indonesian Ocean, East: Bima Regency, West Side: Sumbawa Regency.

2. Factors That Affect the Transfer of Forest Function into Corn Farm In Dompu Regency

Rapid population growth has led to increased demand for land and forest products. In order to meet the increasing need for land and forest products, the government provides business opportunities in forest areas without changing the status and function of forest areas such as granting permits for the use of forest areas for non-forestry purposes $(F$, 2014). But we must not abuse it so that it can 
cause massive environmental damage. . Over the past ten years, flood disasters in The Indonesian region as a result of land damage and watersheds occurred continuously with intensity, frequency, and distribution or affected areas are increasing and expanding (Hakim, 2010), one of them in Dompu Regency. Human resources will cause a change in the ecosystem that will affect the sustainability of natural resources itself (Siliwangi, 2014). Forest damage caused by the clearing of agricultural land by irresponsible people is now increasingly massif. The clearing of corn farming land by damaging forests in Dompu Regency is not without cause. Incandescent program (cow and corn) under the leadership of Haji Bambang Yasin (HBY) for almost 10 years has indeed ushered this area in the east of Sumbawa Tilau as an area that always gets many awards both National, and International. In recent years Dompu has been troubled by the increasingly bare forests around it. It is also influenced by the increasing demand for corn causing the price of corn to increase, making farmers more motivated to switch the function of the forest to corn farming (Nadeak, 2018)

The area of forest cover in NTB is $1,071,722$ due to aggressive encroachment activity and almost in all areas. In Dompu Regency with an area of 232,455 hectares, the remaining 51,482 hectares for protected forest areas, out of a total of 139,892 areas. Land transfer tends to be a problem (negative) in the agricultural sector, but there are still many agricultural lands that are switched because of economic pressures in times of economic crisis or low yields in agriculture causing many farmers to sell their land assets in the form of plantations or rice fields to meet the needs of their lives that indirectly lead to increased function of agricultural land and further increase land tenure parties with high capital (Nurhapsah, 2019).

There are several factors that affect the transfer of forest function to corn farming in Dompu Regency:

1. Isolation (related to population conditions), the increasing number of residents leads to an increasing number of needs such as economic needs, agricultural land needs so that this factor.

2. Showing the availability of land due to the condition of the population more and more. Land transfer can also be interpreted as a change for other uses due to factors that broadly include the need to meet the needs of a growing population and increasing demands for a better quality of life (Hidayat, 2019).

3. Land Use (for its own benefit), deforestation done by some people to be used as their own agricultural land, this factor indicates one of the causes of the transfer of forest functions due to selling value.

4. The economy, with increasing standard of living and needs that become the driver.

5. Weak system of legislation and law enforcement of existing regulations.

6. show the decline of land due to the condition of the population more and more. Land transfer can also be interpreted as a change for other uses due to factors that broadly include the need to meet the needs of a growing population and increasing demands for a better quality of life (Hidayat, 2019).

7. Land Use (for its own benefit), deforestation done by some people to be used as their own agricultural land, this factor indicates one of the causes of the transfer of forest functions due to selling value.

8. The economy, with increasing standard of living and needs that are the drivers.

9. Weak system of legislation and law enforcement of existing regulations.

According to Ilham $\mathrm{N}$ et al.(2005), the determining factors of land transfer are economic, social, and land regulations. The transfer of functions is influenced by population growth factors, rapid economic development, and poverty (Saputra \&Budhi2, 2015). On forest land, the tightness of the soil surface closure by the canopy of the lower plant tree, and the serserah layer is very helpful in maintaining the total amount of organic matter of the soil. meanwhile, on maize planting land has a lower organic matter compared to forests, but has sandy clay, and has the highest level of soil, as well as understorey levels. High levels of shale are suspected because corn trees reduce the absorption of groundwater and can cause flooding and others. Such conditions cause land for forest and maize allocation to have the highest macro pores. In addition to the input of organic matter, the activity of earthworms and plant roots is also very influential in maintaining soil porosity. It is better to transfer the function of forest land can be minimized immediately, although the transfer of forest land function to agricultural 
land is very beneficial for the surrounding community because to improve the economy of the community but this will also be detrimental also because in addition to the

\section{CONCLUSION}

Based on the results of the research, it can be concluded that, the forest has performed its function but as a social being that is not selfish is to maintain and not damage the function of the forest by performing the transfer of forest functions. The change from forest to corn farm will cause changes in vegetation structure and composition of growing species, as well as the layers of soil surface, this condition in the canyon has an impact on the loss of biodiversity native habitat above ground level mainly due to the influence of compaction and decrease in macro pores due to tree felling and management conducted in Dompu Regency. As for some factors that affect the transfer of forest functions into maize farming land in Dompu ialan district of displacedness (related to population conditions), the increasing number of residents leads to an increasing number of needs such as economic needs, agricultural land needs so that this factor indicates the availability of land due to the condition of the population more and more.

Land transfer can also be interpreted as a change for other uses due to factors that broadly include the need to meet the needs of a growing population and the increasing demand for better quality of life (Hidayat, 2019), land use (for self-interest), deforestation done by some people to be used as agricultural land itself, this factor shows one of the causes of forest function transfer due to the selling value, the economy, with increasing living standards and needs that are the driver, and the weak system of legislation and law enforcement of existing regulations.

\section{Acknowledge}

Thank you to all parties who have played a role in the preparation of scientific work "Factors Causing the Transfer of Forest Functions into Corn FarmLand In Dompu Regency". We would like to express our deep gratitude to the community leaders, and the Dompu Regency Government who have provided information to us about land transfer. We also give thanks to the lecturers who have provided mind assistance for the improvement of this scientific paper.

\section{References}

loss of ecosystems in the forest it can also lead to natural disasters that will later threaten the lives of the surrounding community (Bella \& Rahayu)

Bella, H.M. \& Rahayu, , 2021. AlihFungsi Lahan Hutan Menjadi Lahan Pertanian Di Desa Berawang, KecamatanKetol, Kabupaten Aceh Tengah. Pros. SemNas. Peningkatan Mutu Pendidikan, Volume2, pp.88-91.

Devrayno, 2015. Alih Fungsi Lahan Hutan Untuk Perkebunan Prespektif Kebijakan. Jurnal Morality, II, P.6.

Hakim, M.L., 2010. Dampak Alih Fungsi Lahan Terhadap Keberlanjutan Suplai Air Di Waduk Sutami, Malang, Jawa Timur. Jurnal Ilmiah, 13, P.27.

Hidayat, S., 2019. Dampak Pengalih Fungsian Lahan Hutan Jati Menjadi Lahan Pertanian Jagung Terhadap Kondisi Sosial Ekonomi Masyarakat Di Sekitar Kecamatan Katobu Kabupaten Muna. Penelitian Pendidikan Geograf, Volume 4, P.14.

Irawan, B., 2005. Konversi Lahan Sawah : Potensi Dampak, Pola Pemanfaatannya, Dan Faktor Determinan. Forum Penelitian Agro Ekonomi, 23 No. 1, Juli 2005 : 1 - 18, P.8.

Irfan F, M., 2014. Tinjauan Yuridis Implementasi Kewenangan Pemerintah Kabupaten Sinjai Dalam Alih Fungsi Hutan Lindung Menjadi Hutan Produksi. Skripsi. Makasar: Https://Core.Ac.Uk Universitas Hasanuddin Makasar.

Kapantow, G.H.M., Kumaat, R.M. \& Sondak, L.W.T., 2015. Faktor- Faktor Yang Mempengaruhi Alih Fungsi Lahan Pertanian Di Kabupaten Minahasa Selatan Vinny Indah Lagarense/110314003. Agribisnis Jurusan Sosial Ekonomi Fakultas Pertanian, P.4.

Kusumaningtyas, R. \& Chofyan, I., 2013. Pengelolaan Hutan Dalam Mengatasi Alih Fungsi Lahan Hutan Di Wilayah Kabupaten Subang. Jurnal Perencanaan Wilayah Dan Kota, 13 No.2, P.3.

Maha, R. \& Masbar, R., 2018. Pengaruh Alih Fungsi Lahan Kawasan Hutan Terhadap Perekonomian Indonesia. Jurnal Ilmiah Mahasiswa (JIM), 3, p.319.

Nadeak, T.H., 2018. Motivasi Petani Terhadap Alih Fungsi Komoditi Padi Gogo Menjadi Tanaman Jagung Di Kecamatan Purba, Kabupaten Simalungan. Agriprimatech, II, P.40.

Nurhapsah, 2019. Faktor Pendorong Alih Fungsi Lahan Usaha Tani Kakao Menjadi Usaha Tani Jagung di Desa Tolada 
Kecamatan Malangke Kabupaten Luwu Utara. Skripsi. Makasar:Https://Digilibadmin.Unismuh.Ac.I d/Upload/10091-Full_Text.Pdf Universitas Muhammadiyah Makassar.

Saputra, I.G.S.W. \& Budhi2, M.K.S., 2015. Studi Alih Fungsi Lahan Dan Dampaknya Terhadap Sosial Ekonomi Petani Jambu Mete Di Kecamatan Kubu, Kabupaten Karangasem. Ekonomi Dan Bisnis, 4.08, P.560.

Siliwangi, B., 2014. Perusakan Lingkungan Akibat Alih Fungsi Kawasan Hutan Dihulu Sungai Citarum Menjadi Kawasan Pertanian Dihubungkan Dengan Undang-Undang Nomor 32 Tahun 2009 Tentang Perlindungan Dan Pengelolaan Lingkungan Hidup. Wawasan Hukum, Vol. 30, P.77.

Tolaka, W., Wardah \& Rahmawati, 2013. Sifat Fisik Tanah Pada Hutan Primer, Agroforestri Dan Kebun Kakao Di Subdas Wera Saluopa Desa Leboni Kecamatan Pamona Puselemba Kabupaten Poso. Warta Rimba, I, P.2.

Zairin, 2016. Kerusakan Lingkungan Dan Jasa Ekosistem. Georaflesia ,Vol : 1, P.38. 
